\title{
TATA, DURASI, DAN FREKUENSI \\ DALAM NOVEL ORANG-ORANG PROYEK \\ KARYA AHMAD TOHARI: (Analisis Struktur Naratif)
}

\author{
Hartono \\ FBS Universitas Negeri Yogyakarta
}

\begin{abstract}
Abstrak
This research study employs the theory of narrative structure by Seymour Chatman. The study aims to describe plot elements comprising kernel and satellite, arrangement, duration, and frequency available in Orang-orang Proyek, a novel by Ahmad Tohari.

The subject of the study was Orang-orang Proyek (2002, the first impression), a novel by Ahmad Tohari, and the focuses were plot elements covering kernel and satellite, arrangement, duration, and frequency. The data were collected through reading and recording. The novel was read and reread and its discourse and sentential and sub-sentential units containing narrative elements were recorded. The data were analyzed using the descriptive qualitative technique.

The research findings show that Orang-orang Proyek contains 44 kernels and 132 satellites. On the basis of its logical order, it reveals that causality order can be parallel with temporal order. Chronologically, the beginning of the story also results, though not directly, in subsequent events. From the relation between the past and the present, the novel shows a tendency that the analeptic occurring before the present was almost the same as that occurring after the present. The novel contains 20 external anachronisms, 18 mixed anachronisms, and 13 internal anachronisms. The duration includes, from the most to the least, scene, summary, distraction, pause, and ellipsis. The dominance of scene, followed by summary, shows that the narrator's role in the story is very small; most parts of the story are expressed through dialogues among characters to make it more interesting. Singular events dominate frequency in the novel, followed by iterative frequency, multiple-singular frequency, and repetitive frequency. Dominant singular events make the novel more lively and interesting.
\end{abstract}

Key words: narrative structure, arrangement, duration, and frequency

\section{A. Pendahuluan}

\section{Latar Belakang Masalah}

Sebuah karya sastra akan menjadi baik dan bernilai estetik tinggi apabila didukung oleh unsur-unsur pembentuk (unsur intrinsik) yang baik dan disusun secara baik dan padu. Ada keterkaitan antarunsur pembentuknya

menjadi satu kesatuan yang padu. Menurut Stanton (via Nurgiyantoro, 1998: 25) unsur-unsur intrinsik karya sastra yang utama di antaranya adalah tema, fakta, dan sarana cerita. Fakta cerita terdiri atas plot, penokohan, dan latar

Plot merupakan unsur fiksi yang penting, bahkan tak sedikit orang menganggapnya sebagai yang terpenting di antara beberapa unsur fiksi yang lain (Nurgiyantoro, 1998: 110). Plot dalam karya fiksi disusun berdasarkan peristiwa-peristiwa yang terjadi dalam cerita. 
Peristiwa-peristiwa yang akan diceritakan dalam sebuah fiksi dan bagaimana cara menceritakannya merupakan salah satu unsur yang penting.

Orang-Orang Proyek adalah salah satu judul novel karya Ahmad Tohari yang terbit tahun 2002. Novel ini merupakan karya Ahmad Tohari yang paling baru. Lewat novel Orang-Orang Proyek ini is ingin memberikan sebuah fakta, dokumen sosial tentang kekuasaan Orde Baru yang banyak menimbulkan penderitaan bagi rakyat. Berbagai peristiwa diceritakan secara menarik dalam struktur cerita yang kompleks. Oleh karena itu, masalah pengembangan struktur plot dalam novel Orang-Orang Proyek menarik untuk diteliti. Selain itu, pengkajian karya fiksi khususnya novel dengan menggunakan pendekatan struktur naratif masih sangat kurang.

Masalah struktur naratif novel Orang-Orang Proyek menjadi masalah dalam penelitian ini. Dewasa ini masih jarang karya sastra yang dianalisis struktur naratifnya. Sebagian besar model analisisnya adalah model analisis struktur dengan mengungkapkan tema, latar, alur, penokohan, dan saranasarana cerita lainnya. Oleh karena itu, dalam penelitian ini dicoba mendekati novel Orang-Orang Proyek dengan model analisis struktural yang berbeda dengan model struktural tersebut, yaitu analisis struktur naratif. Elemen-elemen cerita yang diteliti meliputi kernel dan satelit, tata, durasi, dan frekuensi.

Berdasarkan latar belakang masalah di atas, masalah dalam penelitian ini dapat dirumuskan sebagai berikut. (1) Bagaimanakah wujud kernel dan satelit dalam novel Orang-orang Proyek karya Ahmad Tohari.? (2) Bagaimanakah wujud tata, durasi, dan frekuensi dalam novel Orang-orang Proyek karya Ahmad Tohari?

\section{Tujuan Penelitian}

Tujuan penelitian ini adalah (1) untuk mendeskripsikan elemen-elemen cerita yang meliputi kernel dan satelit dalam novel Orang-orang Proyek karya Ahmad Tohari, (2) untuk mendeskripsikan tata, durasi, dan frekuensi yang ada dalam novel Orangorang Proyek karya Ahmad Tohari.

\section{Landasan Teori}

Pendekatan yang digunakan dalam mengkaji novel Orang-Orang Proyek adalah pendekatan struktural, yang menganalisis unsur-unsur dalam karya sastra itu sendiri. Pendekatan struktural yang akan diterapkan adalah pendekatan struktur naratif yang dikemukakan oleh Chatman (1980). Menurut Seymour Chatman setiap naratif pada dasamya mengandung dua elemen penting, yakni story atau cerita dan wacana (1980:19). Cerita merupakan isi atau rantai dari peristiwa-peristiwa (tindakan dan kejadian) dan eksisten-eksisten (karakter dan latar). Wacana merupakan ekspresi dari cerita atau susunan peristiwa dalam suatu cerita. Kedua istilah ini oleh Kaum Formalis Rusia disebut dengan istilah fabula dan sjuzet (Chatman, 1980: 19-20; Fowler, 1987:158-159).

Peristiwa-peristiwa dalam pengertian naratif adalah aksi dan kejadian, keduanya merupakan perubahan-perubahan keadaan. Satu aksi adalah satu perubahan keadaan yang didatangkan oleh adanya satu agen atau satu perubahan keadaan yang mempengaruhi satu pasien. Jika aksi adalah signifikan-plot, agen atau pasien disebut karakter (Chatman, 1980:84). Peristiwa-peristiwa disusun berdasarkan urutan waktu logika cerita, tidak dengan urutan waktu wacana (Soleh, 1998:264).

Plot dalam teori naratif Chatman terdiri atas unsur kernel, satelit, order, durasi, dan frekuensi. Peristiwa 
plot yang mayor disebut kernel yang berfungsi mengembangkan plot dengan mengetengahkan dan memenuhi pertanyaan-pertanyaan. Kernel merupakan rangka cerita yang diisi oleh satelit-satelit. Di bawah kernel adalah satelit-satelit yang merupakan peristiwa-peristiwa minor. Satelit-satelit dapat dihilangkan tanpa mengganggu logika plot, meskipun akan mengurangi segi estetik naratifnya. Fungsi satelit adalah mengisi, memperluas, melengkapi kernel; satelit-satelit membentuk dagin pada kerangka kernel (Chatman, 1980: 53-54).

Selain kernel dan satelit, yang termasuk dalam elemen-elemen plot adalah urutan, durasi, dan frekuensi. Ketiga elemen plot tersebut diambil dari teori Genette (1980) yang membedakan tiga kategori relasi antara waktu wacana dengan waktu cerita.

Dalam teori naratif, pengertian tata berkaitan dengan selisih antara urutan waktu cerita dengan urutan waktu wacana. Waktu cerita merupakan waktu berlangsungnya peristiwa-peristiwa dalam sebuah cerita, sedangkan waktu wacana merupakan waktu yang diperlukan untuk membaca sebuah wacana sastra. Hubungan antara waktu wacana dan waktu fiksi tidak pemah sejajar, maka mengakibatkan adanya anakroni (Nurgiyantoro, 2003:140).

Menurut Genette (dalam Chatman, 1980: 64) urutan dibedakan antara sekuen-sekuen normal dengan cerita dan wacana memiliki urutan yang sama dan sekuen-sekuen anakroni. Anakroni dibedakan menjadi dua, yaitu analepsis dan prolepsis. Analepsis terjadi ketika wacana memutus arus cerita untuk mengingat peristiwa-peristiwa sebelumnya, sedangkan prolepsis terjadi ketika wacana melompat ke depan, kepada peristiwa-peristiwa yang terjadi sesudah peristiwa-peristiwa perantara atau yang terjadi langsung mengikuti masa kini.

Menurut Genette (lewat Sahid, 1999: 9) ada tiga kemungkinan terjadinya anakroni, yaitu secara ekstemal, internal, dan secara campuran. Anakroni internal terjadi apabila peristiwa-peristiwa anakroni terjadi setelah peristiwa masa kini. Anakroni ekstemal terjadi apabila awal dan akhir peristiwa terjadi sebelum peristiwa masa kini. Anakroni campuran terjadi apabila awal peristiwa anakroni terjadi sebelum peristiwa masa kini, sedangkan peristiwa akhir terjadi setelah masa kini.

Durasi menyangkut relasi antara waktu cerita dengan waktu yang digunakan untuk pembacaan naratif atau waktu wacana. Terjadinya durasi memiliki lima kemungkinan, yaitu: (1) ringkasan, terjadi apabila waktu wacana lebih pendek daripada waktu cerita; (2) ellipsis, serupa dengan ringkasan, kecuali dalam tiadanya waktu dalam waktu wacana itu; (3) adegan, terjadi apabila waktu wacana dengan waktu cerita sama rentangnya; (4) lanturan atau uluran, terjadi apabila waktu wacana lebih panjang daripada waktu cerita; dan (5) pause, serupa dengan lanturan, kecuali dalam hal tidak adanya waktu cerita (Genette dalam Chatman, 1980: 67-78).

Frekuensi membahas perulangan tampilnya suatu peristiwa dalam cerita dengan perulangan penceritaan di dalam teks, atau keseringan muncul dan tidaknya suatu peristiwa dalam wacana. Ada empat tipe frekuensi, yaitu: (1) frekuensi singular, wacana tunggal menceritakan peristiwa cerita tunggal; (2) frekuensi multiple-singular, beberapa kali wacana untuk menceritakan beberapa kali peristiwa; (3) frekuensi repetitive, merupakan beberapa kali wacana untuk peristiwa cerita yang sama; (4) frekuensi iteratif, satu wacana untuk beberapa momen cerita (Genette dalam Chatman, 1980: 78-79, Todorov, 1985: 2530). 


\section{B. Metode Penelitian}

Subjek penelitian ini adalah novel Orang-Orang Proyek karya Ahmad Tohari cetakan pertama Juli 2002 yang diterbitkan oleh penerbit jendela Yogyakarta. Fokus penelitian ini adalah elemen-elemen plot yang meliputi kernel dan satelit, tata, durasi, dan frekuensi Untuk mengumpulkan data penelitian, mula-mula dibaca secara berulangulang novel Orang-Orang Proyek, selanjutnya dari novel tersebut dicari dan dicatat wacana, unit kalimat dan subkalimat yang mengandung unsur-unsur naratif, khususnya elemen-elemen plot yang meliputi kernel dan satelit, tata, durasi, dan frekuensi Keabsahan data dalam penelitian ini diperoleh lewat pertanggungjawaban dari segi validitas dan reliabilitas. Validitas data diperoleh melalui validitas semantic, yaitu penafsiran berbagai peristiwa dilakukan berdasarkan konteks penceritaan. Reliabilitas data diperoleh dengan cara intrarater, yaitu pembacaan dan penafsiran beberapa kali untuk tiap kalimat data, konteks, bab, dan juga keseluruhan novel untuk kemudian dibuat deskripsi peristiwa.

Analisis data dilakukan dengan teknik deskriptif kualitatif. Secara bertahap dianalisis elemen-elemen struktur naratif novel Orang-Orang Proyek dengan menerapkan model teori struktur naratif yang dikembangkan oleh Seymour Chatman. Karena dalam penelitian ini difokuskan pada elemenelemen plot, secara bertahap dianalisis dan dideskripsikan unsur-unsur pembentuk plot, yaitu kernel-kernel, satelit-satelit, tata, durasi, dan frekuensi.

\section{Hasil Penelitian dan Pembahasan \\ 1. Hasil Penelitian}

Novel Orang-orang Proyek sebagai cerita tersusun dalam sejumlah rangkaian peristiwa yang dapat diurai dalam kernel-kernel dan satelit. Kernel meru- pakan peristiwa-peristiwa mayor yang berfungsi mengembangkan plot, sedangkan satelit adalah peristiwaperistiwa yang berfungsi untuk mengisi, memperluas, dan melengkapi kernel, yang dapat diibaratkan daging yang melekat pada kerangka. Berikut ini dipaparkan contoh sebagian kernel dan satelit yang ada dalam novel Orang-orang Proyek karya Ahmad Tohari.

Novel Orang-orang Proyek karya Ahmad Tohari ini mengandung 44 kernel dan 132 satelit.

Dilihat dari urutan logis berbagai peristiwa yang ada dalam novel Orangorang Proyek dapat dilihat bahwa urutan kausalitas bisa seiring dengan urutan temporal, secara kronologis awal ceritanya juga menjadi penyebab dari peristiwa-peristiwa berikutnya, walaupun tidak secara langsung. Kernel 1 menjadi penyebab terjadinya peristiwa dalam kernel 2, kernel dua juga menjadi penyebab terjadinya peristiwa dalam kernel 3. dan seterusnya dari kernel satu sampai dengan kernel 44 .

Berikut ini tabel frekuensi kemunculan unsur-unsur atau elemen plot dalam novel Orang-orang Proyek karya Ahmad Tohari.

\section{Pembahasan \\ a. Analisis Tata}

Novel Orang-orang Proyek karya Ahmad Tohari mengandung anakroni ekstemal 20 buah, anakroni internal 13 buah, dan anakroni campuran sebanyak 18 buah. Contoh anakroni eksternal yang ada dalam novel tersebut antara lain adalah:

Ya, jembatan yang empat puluh tahun lalu masih berdiri megah, namun kemudian sengaja diledakkan pada tahun 1948. Para pemuda menghancurkan jemba tan itu dalam usaha menghambat laju tanktank tentara Belanda yang mengejar 
mereka.

(Tohari, 2002: 11)

Atau entahlah. Karena bayangan koboi Dalkijo mendadak lenyap dari ingatan Kabul. Sebagai ganti muncul satu-satu bayangan temanteman Kabul pada masa anak-anak. Narsun; anak yang tinggi kurus itu dulu sangat pandai membuat dan bermain gasing. Sekarang dia jadi kuli pembuat batu bata, punya anak lima semuanya kurus, dan mungkin cacingan.....

(Tohari, 2002: 37)

Adalah jiwa Kang Martasatang yang saat ini sedang melayang kembali ke masa lalu. Dulu, bila rakit penyeberangan harus ditambat karena air Sungai Cibawor sangat surut, Kang Martasatang pindah pekerjaan menjadi penangkap ikan.
Bukan dengan kail atau jala, melainkan dengan tangan kosong. Bersama beberapa teman, dulu, Kang Martasatang terkenal jagoan rogoh, atau gogoh, yakni menangkap ikan tanpa alat.

(Tohari, 2002: 156)

Kabul jadi ingat menjelang pemilu 1977 ada peresmian jembatan oleh Wapres. Jembatan itu terletak kurang dari tiga puluh kilometer dari proyek yang sedang dia garap. Peresmiannya juga menjadi ajang kampanye besar GLM. Dan dua tahun kemudian jembatan itu sudah harus diperbaiki karena lantainya jebol.

(Tohari, 2002: 189)

Pada anakroni eksternal seperti pada kutipan di atas jarak antara peristiwa masa lalu dengan masa kini cukup jelas.

Tabel 1: Contoh Kernel dan Satelit

dalam Novel Orang-orang Proyek dalam Ahmad Tohari

\begin{tabular}{|c|c|c|}
\hline No. & Kernel & Satelit \\
\hline 1 & Sungai Cibawor banjir & $\begin{array}{l}\text { 1. Pak Tarya memancing ikan } \\
\text { 2. Pak Tarya meniup seruling }\end{array}$ \\
\hline 2 & Pertemuan Pak Tarya dan Kabul & 1. Kabul mengetahui jati diri Pak Tarya \\
\hline 3 & Banjir merusak pekerjaan jembatan & $\begin{array}{l}\text { 1. Rekomendasi para perancang jembatan diabaikan } \\
\text { 2. Tidak semua pemborong proyek sedih akibat } \\
\text { banjir } \\
\text { 3. Pak Tarya mengenang almarhum ayahnya yang } \\
\text { ditembak mati di jembatan pada tahun } 1948 \text {. }\end{array}$ \\
\hline 4 & $\begin{array}{l}\text { Proyek pembangunan jembatan } \\
\text { Cibawor }\end{array}$ & $\begin{array}{l}\text { 1. Banyak pekerja di proyek jembatan itu } \\
\text { 2. Mak Sumeh yang asli Tegal juga membuka } \\
\text { warung nasi di proyek jembatan itu } \\
\text { 3. Penduduk setempat menyambut proyek jembatan } \\
\text { itu dengan senang hati }\end{array}$ \\
\hline 5 & $\begin{array}{l}\text { Pak Martasatang sedih karena mata } \\
\text { pencahariannya sebagai penarik } \\
\text { rakit penyeberangan hilang. }\end{array}$ & ( \\
\hline 6 & $\begin{array}{l}\text { Pak Tarya dan Kabul memancing di } \\
\text { sungai Cibawor }\end{array}$ & $\begin{array}{l}\text { 1. Kabul mengeluh banyak penduduk yang suka } \\
\text { menyuap para kuli untuk mendapatkan barang } \\
\text { dari proyek } \\
\text { 2. Kabul melamunkan angka kebocoran proyek yang } \\
\text { mencapai } 30 \text { sampai } 40 \text { persen. } \\
\text { 3. Kabul masih perjaka }\end{array}$ \\
\hline dst. & dan seterusnya & dan seterusnya \\
\hline
\end{tabular}


Tabel 2: Frekuensi Kemunculan Elemen Plot dan Jenisnya dalam Novel Orang-orang Proyek

\begin{tabular}{|c|l|ll|c|}
\hline No. & Elemen Plot & \multicolumn{1}{c|}{ Varian } & Frekuensi \\
\hline 1 & Tata & 1. & Anakroni Eksternal & 20 \\
& & 2. & Anakroni Internal & 13 \\
& & 3. & Anakroni Campuran & 18 \\
\hline 2 & Durasi & 1. & Durasi Ringkasan & 41 \\
& & 2. & Durasi Elipsis & 6 \\
& & 3. & Durasi Adegan & 58 \\
& & 4. & Durasi Lanturan & 20 \\
& & 5. & Durasi Pause & 13 \\
\hline 3 & \multirow{2}{*}{ Frekuensi } & 1. & Frekuensi Singular & 129 \\
& & 2. & Frekuensi Multiple Singular & 11 \\
& & 3. & Frekuensi Repetitip & 7 \\
& & 4. & Frekuensi Iteratif & 26 \\
\hline
\end{tabular}

Pada kutipan pertama ada pengungkapan dengan menyebut angka tahun secara jelas, yaitu tahun 1948 dan ditambah dengan deskripsi peristiwa yang terjadi, yaitu penghancuran jembatan tersebut bertujuan untuk menghambat laju tentara Belanda yang mengejar mereka. Di sini jelas, tahun 1948 adalah terjadi peristiwa agresi Belanda yang ditentang oleh bangsa Indonesia.

Penyebutan angka tahun secara jelas juga terjadi pada kutipan keempat pada bagian kalimat pertama yang berbunyi "menjelang pemilu 1977". Penyebu tan angka tahun dan juga peristiwa yang menunjukkan kejadian tertentu yang dapat dirunut waktunya memperjelas jarak antara waktu peristiwa masa lalu dengan masa sekarang.

Anakroni berjenis campuran dalam novel Orang-orang Proyek sebanyak 18 buah hanya selisih dua buah dengan anakroni jenis eksternal. Contoh anakroni campuran dalam novel Orang-orang Proyek tersebut antara lain adalah:

Kabul sering merenungkan seloroh Dalkijo ini. Ya, dengan pandangan dekat, seloroh itu ada benarnya juga. Negeri ini dihuni oleh masyarakat korup, terutama di kalangan birokrat sipil maupun militer, juga orang awamnya. Malah Ka- bul melihat jenis korupsi baru yang tersamar namun bisa sangat parah akibat yang ditimbulkannya. Yakni korupsi melalui manipulasi gelar kesarjanaan.

(Tohari, 2002: 65)

Namun Kabul gagal menahan diri untuk tidak berpikir lebih jauh; bila terhadap proyek tingkat sedang seperti yang sedang dia garap terjadi kebocoran anggaran sedemikian besar, hal yang lebih gigantik tentulah terjadi juga pada megaproyekmegaproyek yang ada di seluruh Indonesia. Juga bank-bank pemerintah, Pertamina, tambang tembaga, Bulog, Perusda,

(Tohari, 2002: 181)

Pada anakroni campuran sebagaimana yang ada pada kutipan di atas jarak antara peristiwa masa kini dengan masa lalu tidak jelas. Kalimat "Negeri ini dihuni oleh masyarakat korup, terutama di kalangan birokrat sipil maupun militer, juga orang awamnya." Masyarakat korup di negara Indonesia ini tidak jelas kapan mulainya dan kapan berakhirnya. Sampai sekarang, masyarakat korup ini masih ada di negeri ini. Peristiwa ini dapat berlaku secara tidak terbatas hingga 
masa kini bahkan dapat juga terjadi pada masa-masa yang akan datang.

Demikian juga dengan apa yang dipikirkan oleh Kabul tentang kebocoran anggaran yang lebih besar yang terjadi pada megaproyek di Indonesia, yang dapat dilihat pada kutipan yang kedua tersebut. Dalam peristiwa tersebut tidak jelas jarak antara peristiwa masa kini dan masa lalu. Peristiwa kebocoran anggaran dapat terjadi pada masa lalu, tapi masa sekarang juga masih terjadi dan pada masa mendatang juga masih mungkin terjadi kebocoran anggaran proyek.

Anakroni internal dalam novel ini sebanyak 13 buah. Contoh anakroni internal dalam novel ini antara lain adalah:

Yakni andaikan proyek-proyek yang saya tangani dikerjakan tanpa penyelewengan dan kecurangan apa pun. Tetapi ternyata saya tak bisa. Proyek ini dibangun dengan rayap-rayap yang doyan batu, semen, besi, apalagi duit. Jelas, yang berdiri nanti adalah jembatan-jembatanan, tapi biaya yang dikeluarkan dan harus jadi beban rakyat bisa untuk membangun dua jembatan yang memenuhi standar mutu. (Tohari, 2002: 88) Malam yang entah mengapa, terasa sangat melelahkan. Kedatangan Baldun masih menyisakan kesan yang menyebalkan. Atau Baldun tidak akan mainmain dengan ancamannya; lapor kepada Ir. Dalkijo bahwa Kabul tidak kooperatif terhadap kepentingan GLM. Atau lagi, Ir. Dalkijo yang nyatanya adalah tokoh GLM akan memecat Kabul karena ternyata tidak loyal. (Tohari, 2002: 187)

\section{b. Analisis Durasi}

Novel Orang-orang Proyek mengandung 138 durasi. Durasi jenis adegan lebih mendominasi (58 buah) dibandingkan dengan durasi yang lain, yakni masing-masing ringkasan 41 buah, lan- turan 20 buah, pause 13, dan elipsis 6 buah. Dominasi durasi adegan sebagai durasi terbanyak disusul durasi ringkasan pada posisi kedua menunjukkan bahwa peran narator dalam novel ini sangat sedikit, sebagian besar cerita disampaikan lewat dialog antartokoh sehingga lebih menarik.

Adegan sebagian besar peristiwanya adalah aktivitas yang dilakukan oleh para tokoh ceritanya. Dalam novel Orang-orang Proyek karya Ahmad Tohari ini peristiwa-peristiwa yang berupa adegan banyak berkaitan dengan aktivitas fisik dan mental terutama yang dilakukan oleh Ir. Kabul, Pak Tarya, Ir. Dalkijo, dan Wati sebagai tokoh utama dan jugs tokoh-tokoh yang lain. Durasi adegan yang mendominasi cerita novel ini dapat membuat cerita tampak lebih hidup seperti dalam kehidupan sehari-hari. Contoh durasi berjenis adegan tersebut adalah sebagai berikut.

"Itulah yang membuat saya tertekan, pusing. Karena beton pancang sudah miring, maka pekerjaan harus diulang dari awal lagi. Nah, bila kau merasa pusing Pak Tarya, kau bisa menghibur diri dengan main suling. Tapi saya?"

"O, begitu? Rupanya sampean pusing karena banjir telah merusak pekerjaan sampean?"

(Tohari, 2002: 7)

"Memang sih, Pak, sekarang ini di mana tidak ada orang edan? Jajaran birokrasi pemerintah, gudangnya. Jajaran penegak hukum, tentara, Depdikbud, Depag, sama saja. Pengusaha, kontraktor, bankir, tak ada beda." "Wakil rakyat?"

"He-he. 'Wakil Rakyat' kan cuma topeng. Isinya nggih sami."

(Tohari, 2002: 86) 
“Maaf, Pak Dalkijo. Kalau keputusan Anda sudah final, saya pun tak mungkin berubah. Saya tetap mengundurkan diri."

(Tohari, 2002: 257)

Ketiga kutipan di atas dapat dimasukkan sebagai durasi adegan karena peristiwa-peristiwa tersebut berkaitan dengan aktivitas fisik dan mental para tokoh dart antara waktu wacana dengan waktu cerita sama. Dominasi jumlah durasi adegan menunjukkan novel ini tidak banyak melibatkan suara narator atau campur tangan pengarang. Pengarang memanfaatkan tokoh ceritanya untuk menyampaikan pandangannya terhadap berbagai peristiwa melalui dialog yang dilakukan oleh tokoh cerita.

Selanjutnya, jenis durasi terbanyak kedua adalah ringkasan (41 buah). Durasi jenis ringkasan ini cenderung menjelaskan berbagai peristiwa kepada pembaca. Kebanyakan peristiwa-peristiwa yang diringkaskan adalah peristiwa masa lalu dan juga peristiwa-peristiwa sehari-hari yang terjadi di lingkungan kehidupan para tokoh cerita. Contoh durasi jenis ringkasan tersebut adalah sebagai berikut.

Tanpa terasa proyek sudah berjalan tiga bulan.

(Tohari, 2002: 28)

"Aku tiga hari telasar-telusur di sana.

Malam hari di terminal ada anak nawarin cimeng. Juga koplo. Nah, aku teler sehari semalam di bangku terminal. Ketika bangun, dompet sudah hilang. Brengsek!"

(Tohari, 2002: 166)

Akhir Desember 1992, hanya satu tahun setelah Kabul meninggalkan proyek pembangunan jemba tan Sungai Cibawor.

(Tohari, 2002: 281)
Peristiwa-peristiwa yang ada dalam kutipan-kutipan tersebut jelas memerlukan banyak waktu. Pada kutipan pertama, lama waktunya tiga bulan, yang kedua tiga hari, dan yang ketiga sehari semalam. Namun demikian, berbagai peristiwa itu hanya diungkapkan dengan beberapa kalimat saja, bahkan ada yang hanya dengan satu kalimat, yaitu pada kutipan pertama.

Jenis durasi berikutnya adalah lanturan 20 buah. Peristiwa yang dilanturkan dalam novel Orang-orang Proyek karya Ahmad Tohari ini sebagian besar adalah peristiwaperistiwa yang berkaitan dengan kejadian a tau peristiwa yang memerlukan penjelasan lebih rinci. Dalam durasi lanturan ini selalu melibatkan narator mengenai dialog, maupun ringkasan peristiwa yang ada. Narator biasanya menyampaikan peristiwa dengan mendeskripsikan apa yang dilakukan oleh tokoh cerita dalam peristiwa tertentu. Contoh durasi lanturan dapat dilihat pada kutipan berikut ini.

Kabul masuk ke warung Mak Sumeh, menarik kursi sambil meminta minuman kesukaannya, es the. Kali ini bukan Sonah, melainkan Sri yang melayaninya. Mak Sumeh tidak kelihatan. Tetapi sesaat kemudian terdengar kerincing gelang emas yang memberati kedua tangannya. Tak salah lagi, perempuan Tegal itu muncul dari balik kain. Pakai kaos oblong dan kainnya kendor tanpa stagen.

(Tohari, 2002: 121)

Durasi yang menduduki urutan keempat dalam novel Orang-orang Proyek adalah pause, yaitu durasi yang hampir sama dengan jenis durasi lanturan tetapi waktu ceritanya tidak ada. Contoh durasi jenis pause ini adalah sebagai berikut. 
Mak Sumeh, perempuan Tegal, juga datang dengan warung nasinya. Mak Sumeh yang wartegnya ada di mana-mana tak pernah absen dalam setiap proyek. Di proyek jembatan Sungai Cibawor itu bangunan warung Mak Sumeh adalah yang terbesar.

(Tohari, 2002: 15)

Sungai Cibawor sedang menanggung puncak kemarau. Air surut lebih setengah dari biasanya. Tepiannya yang terjal terlihat lebih dalam. Sosok batu-batu besar yang sering diduduki Pak Tarya waktu mincing makin njenggereng.

(Tohari, 2002: 115)

Durasi yang paling sedikit terdapat dalam novel Orang-orang Proyek adalah durasi jenis elipsis. Durasi elipsis ini hampir sama dengan durasi ringkasan, tetapi yang membedakannya adalah tidak adanya waktu dalam waktu wacana. Contoh durasi elipsis dapat dilihat pada kutipan berikut.

Atau karena bagi Pak Tarya kenikmatan dan kepuasan memancing tidak ada pada enaknya menyentap ikan, melainkan pada tercapainya harapan dan tersingkirnya kegagalan, yakni sport psikologis yang baginya sangat mengasyikkan. Atau lagi, entahlah.

(Tohari, 2002: 114)

Pada saat itu Kabul tak melihat apa pun yang pantas dilakukannya, kecuali minta diri. Ibu Wati menanggapinya dengan sikap dan bahasa pas-pasan saja.

(Tohari, 2002: 150)

Dan selintas Kabul melihat Wati menghapus air mata. Rasanya dia juga mengerti mengapa Wati me- nangis. Hening.

(Tohari, 2002: 195)

Pada kutipan di atas terdapat ringkasan cerita tetapi waktu wacana tidak dimunculkan dalam deskripsi tersebut. Peristiwa bagaimana Pak Tarya menikmati kegia tan memancingnya diringkas menjadi satu kalimat panjang, tetapi waktu wacananya tidak ada. Dalam ellipsis waktu wacana memang ditiadakan.

\section{c. Analisis Frekuensi}

Novel Orang-orang Proyek mengandung 173 frekuensi. Frekuensi jenis singular lebih mendominasi, yaitu sebanyak 129 buah dibandingkan dengan yang lain, yakni masing-masing iteratif 26 buah, repetitif sebanyak 7 buah. Dominasi peristiwa-peristiwa singularis +dalam novel Orang-orang Proyek karya Ahmad Tohari ini membuat cerita dalam novel ini menjadi lebih hidup karena peristiwanya bersifat tunggal. Contoh frekuensi singular adalah sebagai berikut.

"Dan kerusakan itu membuat kerugian yang cukup besar. Serta memberi beban batin karena kerja beberapa hari dengan biaya jutaan lenyap seketika."

(Tohari, 2002: 8)

Bagaimana jika karena sikap Pak Kabul ini masjid belum selesai ketika Pemimpin Umum GLM tiba di sini; Anda mau bertanggung jawab?"

(Tohari, 2002: 182)

Frekuensi iteratif juga diungkapkan oleh pengarang walaupun jumlahnya memang lebih kecil dibandingkan dengan frekuensi singular. Karena jumlahnya lebih kecil, maka kehadiran frekuensi iteratif ini tidak akan mengganggu lebih hidupnya cerita. Berikut 
ini adalah contoh frekuensi iteratif tersebut.

"Pak Tarya, kedua orang tua saya tak kenal Ki Hajar. Namun saya tahu mereka mengikutinya. Dan saya sangat hormat kepada Bapa-Biyung yang memilih hidup ayem dalam kesahajaan; memilih makan nasi inthil, tapi bisa among rasa daripada makan enak sambil mengumbar keinginan yang bermuara pada keserakahan."

(Tohari, 2002: 251)

Frekuensi multiple-singular terjadi dalam novel Orang-orang Proyek ketika para tokoh mengungkap adanya korupsi yang sudah mewabah diberbagai lini kehidupan bernegara dan bermasyarakat. Hal ini sering dilakukan oleh Kabul dan Pak Tarya dalam dialog-dialognya.

Peristiwa berfrekuensi repetitif dalam novel Orang-orang Proyek karya Ahmad Tohari terjadi pada masa lalu atau sudah diceritakan sebelumnya sehingga peristiwa yang diulang-ulang itu melibatkan penceritaan narrator. Fungsi frekuensi repetitif adalah untuk memberi penegasan atau lebih menjelaskan sesuatu hal. Contoh frekuensi ini dalam novel karya Ahmad Tohari tersebut terdapat pada peristiwa pertemuan Pak Tarya dengan Kabul waktu memancing di sungai, juga peristiwa Kabul yang senantiasa mengingat Biyungnya.

\section{Kesimpulan}

Dari penelitian dan pembahasan yang telah dilakukan dapat disimpulkan hal-hal sebagai berikut:

1. Novel Orang-orang Proyek terdiri dari 44 kernel dan 132 satelit. Berdasarkan urutan logis novel dapat diketahui bahwa urutan kausalitas bisa seiring dengan urutan temporal, secara kronologis awal ceritanya juga menjadi penyebab dari peristi- wa-peristiwa berikutnya, walaupun tidak secara langsung. Apabila dilihat dari hubungan masa lalu dengan masa kini, novel Orang-orang Proyek memperlihatkan adanya kecenderungan bahwa analepsis yang terjadi sebelum masa kini hampir sama dibanding dengan yang terjadi setelah masa kini. Novel ini mengandung anakroni eksternal sebanyak 20 buah, anakroni campuran sebanyak 18 buah, dan anakroni internal sebanyak 13 buah.

2. Durasi dalam novel ini secara berurutan dari yang terbanyak adalah adegan (58), ringkasan (41), lanturan (20), pouse (13), dan ellipsis (6). Dominasi durasi adegan sebagai durasi terbanyak disusul durasi ringkasan pada posisi kedua menunjukkan bahwa peran narator dalam novel ini sedikit, sebagian besar cerita disampaikan lewat dialog antartokoh sehingga cerita dapat lebih menarik.

3. Peristiwa singularis (129) mendominasi frekuensi dalam novel Orangorang Proyek, disusul frekuensi jenis iteratif (26), multiple-singular (11), dan frekuensi repetitif (7). Peristiwa peristiwa singularis yang mendominasi frekuensi dalam ini membuat cerita dalam novel Orang-orang Proyek lebih hidup dan menarik.

\section{Daftar Pustaka}

Chatman, Seymour. 1980. Story and Discourse Narrative Fiction and Film. London: Cornel University Press.

Fowler, Roger (ed.). 1987. A Dictionary of Modern Critical Terms. London: Routledge \& Kegan Paul.

Nurgiyantoro, Burhan. 1998. Teori Pengkajian Fiksi. Yogyakarta: Gadjah Mada University Press.

2003. "Tatanan Cerita dan Penceritaan dalam Novel Saman". Li- 
tera, Volume 2, Nomor 2, Juli 2003, hal. 138-154. Yogyakarta: Fakultas Bahasa dan Seni Universitas Negeri Yogyakarta.

Sahid, Nur. 1999. “Tata, Durasi, dan Frekuensi dalam Drama Panembahan Reso: Tinjauan Struktur Naratif." dalam Poetika Jurnal Ilmiah Kesusasteraan. Nomor 2 Tahun XII Edisi Mei - Agustus 1999, Halaman 3 - 37.
Soleh, Rakhmat. 1998. "Hikayat Isma Yatim: Suntingan Teks, Analisis Urutan, Durasi, Frekuensi, dan Penokohan. Tesis S2. UGM

Todorov, Tzvetan. 1985. Tata Sastra (terjemahan Okke K.S. Zaimar, dkk.). Jakarta: Djambatan.

\section{Sumber Data:}

Tohari, Ahmad. 2002. Orang-Orang Proyek. Yogyakarta: Jendela. 